\title{
Examining the link between vegetation leaf area and land-atmosphere exchange of water, energy, and carbon fluxes using FLUXNET data
}

\author{
Anne J. Hoek van Dijke ${ }^{1,2,3}$, Kaniska Mallick ${ }^{1}$, Martin Schlerf ${ }^{1}$, Miriam Machwitz ${ }^{1}$, Martin Herold ${ }^{2}$, and \\ Adriaan J. Teuling ${ }^{3}$ \\ ${ }^{1}$ Remote Sensing and Natural Resources Modelling, ERIN Department, Luxembourg Institute of Science \\ and Technology (LIST), Belvaux, Luxembourg \\ ${ }^{2}$ Laboratory of Geo-Information Science and Remote Sensing, Wageningen University \& Research, \\ Wageningen, the Netherlands \\ ${ }^{3}$ Hydrology and Quantitative Water Management Group, Wageningen University \& Research, \\ Wageningen, the Netherlands
}

Correspondence: Anne J. Hoek van Dijke (anne.hoekvandijke@wur.nl)

Received: 13 February 2020 - Discussion started: 11 March 2020

Revised: 8 July 2020 - Accepted: 19 July 2020 - Published: 4 September 2020

\begin{abstract}
Vegetation regulates the exchange of water, energy, and carbon fluxes between the land and the atmosphere. This regulation of surface fluxes differs with vegetation type and climate, but the effect of vegetation on surface fluxes is not well understood. A better knowledge of how and when vegetation influences surface fluxes could improve climate models and the extrapolation of ground-based water, energy, and carbon fluxes. We aim to study the link between vegetation and surface fluxes by combining the yearly average MODIS leaf area index (LAI) with flux tower measurements of water (latent heat), energy (sensible heat), and carbon (gross primary productivity and net ecosystem exchange). We show that the correlation of the LAI with water and energy fluxes depends on the vegetation type and aridity. Under water-limited conditions, the link between the LAI and the water and energy fluxes is strong, which is in line with a strong stomatal or vegetation control found in earlier studies. In energy-limited forest we found no link between the LAI and water and energy fluxes. In contrast to water and energy fluxes, we found a strong spatial correlation between the LAI and gross primary productivity that was independent of vegetation type and aridity. This study provides insight into the link between vegetation and surface fluxes. It indicates that for modelling or extrapolating surface fluxes, the LAI can be useful in savanna and grassland, but it is only of limited use
\end{abstract}

in deciduous broadleaf forest and evergreen needleleaf forest to model variability in water and energy fluxes.

\section{Introduction}

Vegetation and water, energy, and carbon fluxes are tightly coupled. Large-scale vegetation patterns are driven by the long-term memory of water and energy availability (Köppen, 1936; Prentice et al., 1992; Cramer et al., 2001). Recent climate change has led to shifts in the spatial distribution of vegetation as well as shifts in the timing of the growing season (Jeong et al., 2011; Rosenzweig et al., 2008; Fei et al., 2017). Additionally, vegetation plays a crucial role in the exchange of water, energy, and carbon between the land surface and the atmosphere, mainly through its effects on evapotranspiration, turbulence, the redistribution of water, and surface heating (Shao et al., 2015; Jia et al., 2014; Esau and Lyons, 2002). Large-scale reforestation and afforestation has increased evapotranspiration over most of Europe (Teuling et al., 2019), and large-scale deforestation has increased the air temperature in tropical regions and decreased air temperature in boreal regions (Perugini et al., 2017). This two-way interaction between vegetation and terrestrial surface fluxes has been known for a long time (e.g. Bates and Henry, 1928; 
Woodwell et al., 1978), but it is still a very relevant research topic today (Forkel et al., 2019; Lu et al., 2019; Teuling and Hoek van Dijke, 2020; Kirchner et al., 2020; Evaristo and McDonnell, 2019) given the importance of understanding the impacts of climate change on vegetation as well as the effects of land cover change on climate.

Plants regulate the exchange of water, energy, and carbon with the atmosphere through their stomata. The stomatal regulation of these fluxes depends on available energy, the transpiration demand, and the available soil moisture in the root zone. When both the available energy and soil moisture are abundant, stomata open and water and carbon can freely move in and out: the stomatal control on surface fluxes is low. When the available energy is high but soil moisture is limiting, stomata tend to close and exert a large control on water and carbon fluxes (Mallick et al., 2016; O'Toole and Cruz, 1980). Zooming out from the stomatal to canopy scale, there are several other ways in which vegetation influences surface fluxes. Soil and crown mutual shadowing and deep ground water uptake by vegetation influence the latent heat flux, whereas soil moisture influences ecosystem respiration and, in turn, carbon exchange (Chen et al., 2019; Schmitt et al., 2010). The vegetation control of ecosystem fluxes has been shown by different data or modelling studies and depends on the climate and vegetation type (Williams et al., 2012; Xu et al., 2013; Wagle et al., 2015). Williams and Torn (2015) found a strong vegetation control on surface heat flux partitioning in both arid and humid grassland, cropland, and forest, but Padrón et al. (2017) concluded that, globally, vegetation control on evapotranspiration was low or even absent in the equatorial regions. Chen et al. (2019) showed that temperature, precipitation, and vegetation leaf area explained $91 \%$ of the mean annual variability in vegetation carbon uptake for wetland sites. Mallick et al. (2018) showed that vegetation control on evapotranspiration was stronger in arid ecosystems compared with the mesic ecosystems. Similar results were found for dry and wet Amazonian forest (Costa et al., 2010; Mallick et al., 2016) and dry and wet grassland (De Kauwe et al., 2017). Ferguson et al. (2012) studied landatmosphere coupling of fluxes, which includes the effect of vegetation as well as other factors such as soil wetness, soil texture, and surface temperature. From remote sensing data and model output, they concluded that transitional zones between arid and humid climates (shrublands, grasslands, and savannas) tend to have a strong land-atmosphere coupling, whereas land-atmosphere coupling is weak in the energylimited regions.

Vegetation is coupled to the atmosphere through its leaves. The leaf area index (LAI) is an important vegetation characteristic and is indicative of the total amount of foliage that intercepts light and assimilates carbon. Furthermore, both rainfall interception and canopy conductance increase with the LAI (Van Heerwaarden and Teuling, 2014; Gómez et al., 2001). Therefore, a high LAI is related to high vegetation carbon uptake and high canopy evapotranspiration of water



Figure 1. Global distribution of vegetation leaf area index (LAI). The mean LAI, at $5 \mathrm{~km}$ resolution, is derived from the MODIS data product MCD15A3H.006 (Myneni et al., 2015).

(Lindroth et al., 2008; Duursma et al., 2009). The highest mean yearly LAI is found in tropical and temperate forests, whereas a low LAI is found in cold and in arid climate zones (Fig. 1; Iio et al., 2014; Asner et al., 2003). This global LAI pattern closely resembles large-scale patterns in estimates of water, energy, and carbon exchange (Miralles et al., 2011; Jung et al., 2011). With the increasing availability of remotely sensed LAI data, the LAI - in addition to its usage in many remote sensing applications (e.g. Si et al., 2012; Zheng and Moskal, 2009) - has become a frequently used variable to represent vegetation in land surface models (Williams et al., 2016; Sellers et al., 1997; Lawrence and Chase, 2010 amongst many others) or to estimate or extrapolate regional or global water and carbon fluxes (Beer et al., 2007; Yan et al., 2012; Turner et al., 2003; Xie et al., 2019). The algorithms to retrieve the LAI from remotely sensed data have improved over the past few decades, thereby increasing the accuracy of LAI products (Shabanov et al., 2005; Yan et al., 2016). Nevertheless, it is important to be aware of the product uncertainties, especially over dense forest, where saturated reflectance and canopy clumping can only provide limited information for LAI retrievals (Shabanov et al., 2005; Xu et al., 2018), and at high latitudes, where the solar zenith angle is low (Fang et al., 2019).

The interaction between the vegetation LAI and surface fluxes on the larger scale is not yet well understood, and vegetation is not well represented in many land-atmosphere and climate models (Williams et al., 2016). A small-scale study in temperate deciduous forest, for instance, revealed that the correlation between sap flow and the normalized difference vegetation index (NDVI) can change from positive to negative depending on the season and soil moisture availability (Hoek van Dijke et al., 2019). A detailed knowledge of how and when the vegetation LAI is linked to the surface fluxes is required to improve global climate modelling and extrapolation of water and carbon fluxes from canopy to ecosystems. The high availability of remote sensing LAI products, recent developments in cloud-based platforms for geospatial analysis (Mutanga and Kumar, 2019), and the availability of publicly available eddy covariance data from FLUXNET (Baldocchi et al., 2001) allows for an analysis of the link be- 
tween vegetation characteristics and surface fluxes. Thus, the objective of our study is to gain insight into the link between the vegetation LAI and surface fluxes for different vegetation types along an aridity gradient. We address the following research questions:

1. What is the link between LAI and respective water, energy, and carbon fluxes in different vegetation types?

2. How is the interaction between LAI and respective water, energy, and carbon fluxes governed by climatological aridity?

We hypothesize that the link between the LAI and surface fluxes is strong in semi-arid and arid climates, owing to the strong stomatal control, whereas the link is weak in humid climates.

In our study we focus on five metrics of water, energy, and carbon fluxes measured by flux towers. Latent heat $(L E)$, a measure for the evapotranspiration of water, and sensible heat $(H)$, represent the exchange of water and energy between the Earth's surface and the atmosphere. $L E$ and $H$ are linked through the evaporative fraction $(\mathrm{EF})$. The EF is the ratio of latent heat to the sum of $L E$ and $H$ and is a useful measure of the partitioning of total available energy between the evapotranspiration of water and surface heating. Net ecosystem exchange (NEE) is the net exchange of carbon between the land and the atmosphere, which is directly measured by flux towers. Gross primary productivity (GPP) is derived from the NEE and is the gross uptake of atmospheric carbon by the vegetation.

\section{Data and methodology}

\subsection{Data}

\subsubsection{Data selection}

This study includes five vegetation types: savanna (SAV), grassland (GRA), deciduous broadleaf forest (DBF), evergreen broadleaf forest (EBF), and evergreen needleleaf forest (ENF). The SAV sites include the two classes "savanna" and "woody savanna". These vegetation types follow the International Geosphere-Biosphere Programme (IGBP) classification (Loveland et al., 2000). These five vegetation types were selected because of the availability of a high number of flux tower sites. For some "site-years" (a term used to refer to the yearly averaged values for every site), the LAI flux or meteorological measurements were not available. These site-years were included in each of the analyses for which the required metrics were available.

Within the FLUXNET2015 dataset (Baldocchi et al., 2001), we selected all Tier 1 sites (open and free for scientific purposes; Pastorello et al., 2020) within the five studied vegetation types. We completed the dataset with two sites from the OzFlux network to increase the number of sites in the EBF class (Liddell, 2013a, b). Two forest sites were excluded from the analyses because they were affected by a beetle outbreak that resulted in high tree mortality, and one heavily managed grassland site was excluded from the analysis. For each site, only years with good-quality data were selected; this was carried out following the quality selection procedure explained below. This site selection procedure, in combination with the quality check, resulted in a dataset of 545 site-years spread over 93 sites (Fig. 2, Table 1).

\subsubsection{Data averaging and aggregation}

We studied the yearly averaged LAI and surface fluxes for different vegetation types. For most vegetation types, the LAI and surface fluxes showed seasonal variability, with high values during the growing season and lower or zero LAI and surface fluxes during the cold or dry season. The non-growing season might not be relevant for finding the link between the LAI and surface fluxes, but selecting growing season values alone led to difficulties. The vegetation types differ with respect to the timing, number, and length of the growing seasons, and procedures such as time-series analysis did not successfully select the growing seasons. To be consistent in the methodology, yearly averaged fluxes were used for all flux tower sites. Using yearly averaged values for every site (siteyears) has a few implications: (1) we study both spatial (siteto-site) variability and temporal (year-to-year) variability simultaneously, and (2) the averaged flux and meteorological measurements might not represent similar conditions. The latter occurs, for example, when a site-year receives plenty of precipitation in December, increasing the site-year's aridity index, while this precipitation mainly impacts the next site-year's fluxes or LAI values. To test the effect of using site-year data, we also studied spatial and temporal variability separately. For these analyses, the data were aggregated in three ways: (1) site-year data with one average value per site per year; (2) multi-year data with one multi-year average LAI and flux value per site, which were used to study the spatial correlation; and (3) yearly average data for a few sites, which were used to study the temporal correlation. Sites were included in the multi-year data if at least 3 years of data were available. The three aggregation methods led to similar conclusions for water and energy but slightly different results for carbon, as is shown in the paper.

\subsubsection{Flux measurements}

Within the FLUXNET2015 database, $L E, H$, NEE, and GPP measurements are gap-filled using the MDS (marginal distribution sampling) method (Reichstein et al., 2005), and $L E$ and $H$ are corrected by an energy balance closure correction factor. The MDS method uses the correlation of fluxes with the driver variables (incoming radiation, temperature, and vapour pressure deficit) to estimate flux values during gap periods. The energy balance closure corrects $L E$ and $H$ 


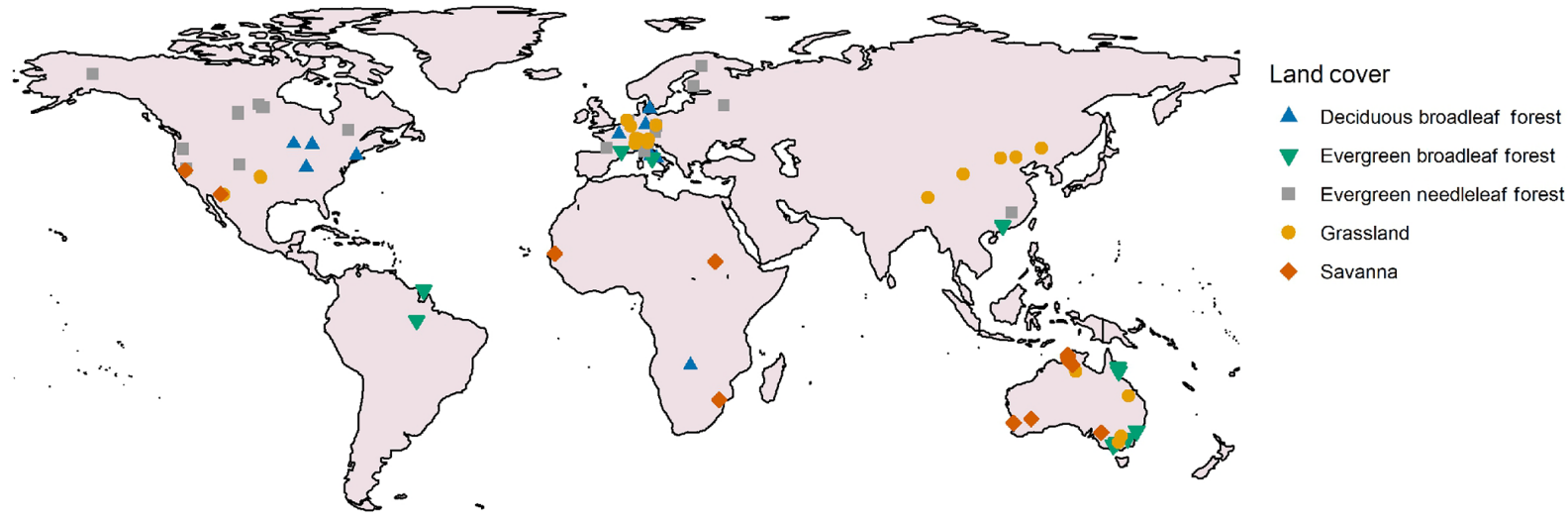

Figure 2. Location and vegetation type of the 93 included flux tower sites.

for the total incoming radiation, assuming that the Bowen ratio (the ratio of the sensible heat flux to the latent heat flux) is correct. A similar energy balance closure correction was applied to the $L E$ and $H$ measurements of the OzFlux sites. Monthly averaged flux values were discarded if the percentage of measured and good-quality gap-fill data was below $50 \%$. Yearly average fluxes were calculated if measurements for each month were available. The evaporative fraction $(\mathrm{EF})$, the ratio between $L E$ and the total energy available at Earth's surface, was calculated using Eq. (1) as follows:

$\mathrm{EF}=\frac{L E}{L E+H}$,

where $L E$ is the latent heat flux and $H$ is the sensible heat flux.

\subsubsection{Meteorological measurements}

Meteorological measurements are delivered with the flux tower data. Precipitation data are downscaled from the ERAInterim reanalysis data (Vuichard and Papale, 2015). Net radiation and air temperature are measured at the flux tower and gap-filled using the MDS method (Reichstein et al., 2005). Yearly potential evaporation $\left(E_{\mathrm{p}}\right)$ was calculated from mean daily air temperature and net radiation using the Priestley-Taylor formulation (Priestley and Taylor, 1972). The Priestley-Taylor equation is a modification of the Penman equation and requires less measurements. The aridity index (AI), an indicator of dryness, was calculated according to Eq. (2):

$\mathrm{AI}=\frac{P}{E_{\mathrm{p}}}$,

where $P$ is precipitation and $E_{\mathrm{p}}$ is the potential evaporation. An aridity value of one indicates that, on a yearly scale, precipitation equals potential evaporation, whereas values below one indicate site-years that received less precipitation than their potential evaporation.

\subsubsection{Leaf area index}

The leaf area index (LAI) is the ratio of green leaf area to ground area (unitless). We used the LAI derived from the MODIS data product MCD15A3H.006 (Myneni et al., 2015). This algorithm derives $4 \mathrm{~d}$ composite LAI values at a $500 \mathrm{~m}$ spatial resolution from the Terra and Aqua satellites and is available for 2003 onwards. Within this $4 \mathrm{~d}$ period, the best pixel is selected from the MODIS sensors located on the Terra and Aqua satellite for the calculation of the LAI. The LAI calculation algorithm uses a lookup table that was generated using a 3D radiative transfer equation (Myneni et al., 2015). Heinsch et al. (2006) compared the MODIS data product with ground measurements at FLUXNET sites and concluded that $62.5 \%$ of the MODIS LAI was well estimated but that MODIS LAI overestimated ground-measured LAI for the other sites. Despite this overestimation, MODIS LAI was used because it has a long record length, good (and free) data availability, good spatial coverage, and high temporal resolution. The overestimation and saturation of the signal at high LAI could introduce noise in the LAI data. However, we do not expect this noise to change the conclusions of our analysis. The resolution of the LAI data product is $500 \mathrm{~m}$, compared with a typical flux tower footprint length of 100 to $1000 \mathrm{~m}$ (Kim et al., 2006). The exact size and location of the footprint of flux towers, however, varies with factors such as wind direction and wind speed, surface roughness, and flux measurement height (Kim et al., 2006; Barcza et al., 2009). For our analyses, we selected the one nearest LAI pixel for each flux tower. Data were filtered to remove clouds, using the product's delivered quality label. To smoothen outliers, the moving mean LAI was calculated for three consecutive data points. Monthly mean values were calculated if a maximum of one data point was missing. The site-year average LAI was calculated when no monthly data were missing. 


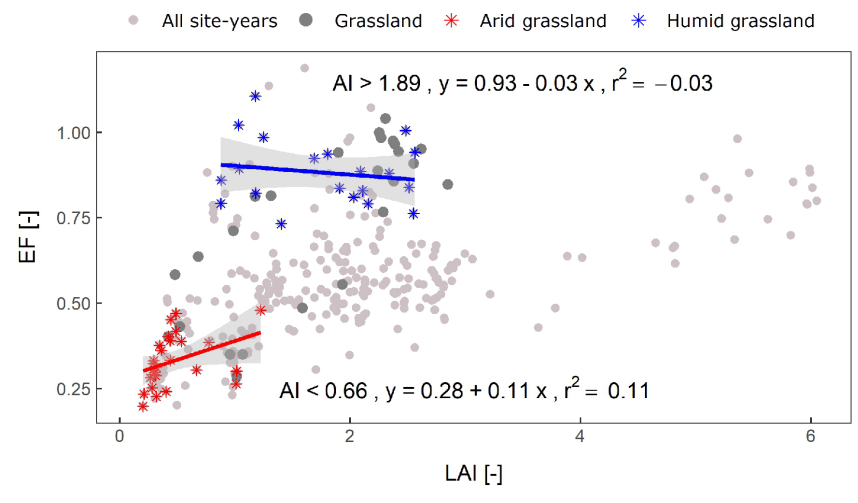

Figure 3. Illustration of the applied methodology. The correlation coefficient between leaf area index (LAI) and evaporative fraction $(\mathrm{EF})$ is calculated for 30 site-years for grassland over a moving window of aridity index. In the illustration, the correlation has a significant positive slope at $p=0.056$ for the 30 most arid grassland sites, whereas the slope is nearly flat and is not significant $(p=0.49)$ for the 30 most humid grassland sites.

\subsection{Methodology}

To study the link between the LAI and surface fluxes, we performed a linear regression between the LAI and the surface fluxes. We calculated the correlation coefficient for (1) siteyear data, (2) multi-year average data (spatial variability), and (3) yearly data for a few specific sites (temporal variability). Afterwards, to study if the link between the LAI and fluxes changed with aridity, all site-years within one vegetation type were ranked by aridity, from most arid to most humid. For each consecutive 30 site-years in this ranking, we performed a linear regression between the LAI and the fluxes. For some site-years, part of the data was missing that was needed to calculate the regression. Within each window of 30 site-years, the slope of the regression was calculated if at least 15 complete site-years were available (Fig. 3).

\section{Results}

\subsection{The link between LAI and the respective water, energy, and carbon fluxes}

LAI and $L E$ were positively correlated in SAV, GRA, and EBF (Fig. 4, Table 2). The slope of the correlation between the different vegetation types is different; the slope was steepest for SAV (slope $=46.1 \mathrm{~W} \mathrm{~m}^{-2}$ ): a twofold increase in the LAI ( 1 to 2$)$ was associated with an almost twofold increase in $L E$ (51 to $97 \mathrm{~W} \mathrm{~m}^{-2}$ ), compared with a flatter slope in GRA $\left(9.80 \mathrm{~W} \mathrm{~m}^{-2}\right)$ and EBF $\left(13.0 \mathrm{~W} \mathrm{~m}^{-2}\right)$. In ENF and DBF, the LAI and $L E$ were not significantly correlated. LAI and $H$ were negatively correlated in SAV, GRA, and EBF, whereas there was no significant correlation in ENF and DBF. The LAI and the EF were positively correlated in SAV, GRA, and EBF, whereas no correlation was found in
ENF and DBF. A positive slope indicates that, for a higher LAI, a higher fraction of the available energy is used for the evapotranspiration of water, compared with surface heating. The slope between the LAI and EF was steeper in SAV and GRA (slope $=0.27$ for both) than in EBF (slope $=0.08$ ). A positive correlation between LAI and GPP was found in all vegetation types $(r=0.47-0.97)$, with a very strong correlation coefficient for SAV $(r=0.97)$. The correlation followed a steep slope for SAV (slope $=3.37 \mathrm{gC} \mathrm{m}^{-2} \mathrm{~d}^{-1}$ ) and GRA (slope $=2.17 \mathrm{gC} \mathrm{m}^{-2} \mathrm{~d}^{-1}$ ), a similar slope in EBF (slope $=1.71 \mathrm{gC} \mathrm{m}^{-2} \mathrm{~d}^{-1}$ ) and ENF (slope $=1.81$ $\mathrm{gC} \mathrm{m}^{-2} \mathrm{~d}^{-1}$ ), and a less steep slope in DBF (slope $=0.76$ $\mathrm{gC} \mathrm{m}^{-2} \mathrm{~d}^{-1}$ ). The correlation between the LAI and NEE was negative in SAV, EBF, and ENF. This indicates that the net carbon uptake increases with the LAI. Among the different fluxes, GPP showed the strongest correlation with the LAI for all vegetation types. Comparing the different vegetation types, the correlation between the LAI and fluxes was strongest in SAV.

Using multi-year average data reduced the number of data points to only 5 to 16 sites per vegetation type. Nevertheless, the spatial correlation (site-to-site variability) between the LAI and surface fluxes is very similar to the spatio-temporal correlation (Fig. 5, Table 2). For SAV, GRA, and ENF, the slope and strength of the correlation were similar when compared with the site-year data. For the EBF, for the site-year data, the correlation with $L E$ and $\mathrm{EF}$ was only significant at $p \leq 0.1$, and the correlation was not significant for $H$ and NEE.

LAI and surface fluxes were low, and the variability in fluxes was not significantly correlated with variability in the LAI.

\subsection{The effect of climatological aridity on the link between LAI and surface fluxes}

Figure 7 shows the steepness and significance of the correlation between the LAI and surface fluxes for different aridity values. In dry vegetation types or regions, the correlation between the LAI and fluxes was significant and had a steeper slope, whereas in the more humid vegetation types or regions, the slope was relatively horizontal and the correlation was often not significant. In SAV, GRA, and EBF, the correlation between the LAI and $L E$ was significant for the whole range of aridity values. In arid GRA, the correlation had a steeper slope compared with humid GRA. With respect to the LAI versus $H$ and LAI versus EF, the slope was steep and significant for SAV. For GRA, the correlation was strong and significant in the arid regions and insignificant in the humid regions. For EBF, the slope and the significance of the correlation did not change with aridity. For LAI and GPP, the slope and the significance of the correlation did not change with aridity for SAV, GRA, EBF, and ENF. For DBF, the correlation between the LAI and GPP was negative at higher aridity, but these results were strongly influenced 
Table 1. A list of all included site-years for the 93 sites. For each site, the yearly average leaf area index (LAI) and aridity index (AI) are calculated for all years included in the dataset. Studied vegetation types include the following: savanna (SAV), woody savanna (woody SAV; savanna and woody savanna sites are combined into one class, "savanna"), grassland (GRA) deciduous broadleaf forest (DBF), evergreen broadleaf forest (EBF), and evergreen needleleaf forest (ENF).

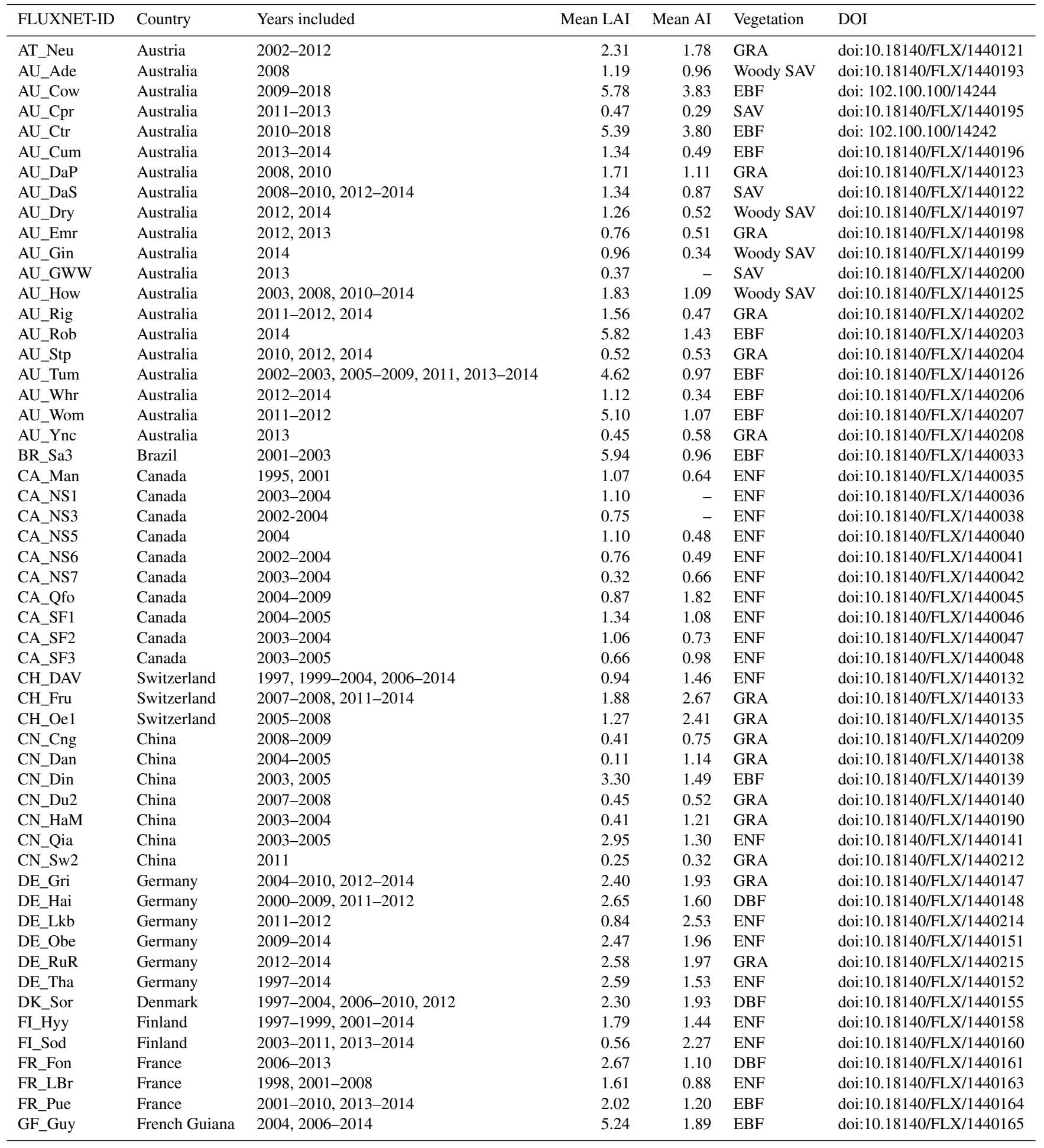


Table 1. Continued.

\begin{tabular}{|c|c|c|c|c|c|c|}
\hline FLUXNET-ID & Country & Years included & Mean LAI & Mean AI & Vegetation & DOI \\
\hline IT_CA1 & Italy & 2012,2014 & 1.23 & - & DBF & doi:10.18140/FLX/1440230 \\
\hline IT_CA3 & Italy & 2012,2013 & 1.16 & 1.03 & DBF & doi:10.18140/FLX/1440232 \\
\hline IT_Col & Italy & $2007,2009,2011,2014$ & 2.32 & 1.53 & DBF & doi:10.18140/FLX/1440167 \\
\hline IT_Cp2 & Italy & 2013 & 3.84 & 0.93 & EBF & doi:10.18140/FLX/1440233 \\
\hline IT_Cpz & Italy & 2003, 2006, 2007 & 3.12 & 0.89 & EBF & doi:10.18140/FLX/1440168 \\
\hline IT_Isp & Italy & 2013,2014 & 1.66 & 2.41 & DBF & doi:10.18140/FLX/1440234 \\
\hline IT_Lav & Italy & 2003-2013 & 2.55 & 1.74 & ENF & doi:10.18140/FLX/1440169 \\
\hline IT_MBO & Italy & 2003-2013 & 1.16 & 2.41 & GRA & doi:10.18140/FLX/1440170 \\
\hline IT_PT1 & Italy & 2003 & 0.81 & 0.77 & DBF & doi:10.18140/FLX/1440172 \\
\hline IT_Ren & Italy & $2003,2005-2013$ & 1.53 & 1.60 & ENF & doi:10.18140/FLX/1440173 \\
\hline IT_Ro1 & Italy & $2002-2006$ & - & 0.91 & DBF & doi:10.18140/FLX/1440174 \\
\hline IT_Ro2 & Italy & 2002-2007, 2012 & 1.99 & 0.83 & DBF & doi:10.18140/FLX/1440175 \\
\hline IT_SR2 & Italy & 2013 & 2.12 & 1.38 & ENF & doi:10.18140/FLX/1440236 \\
\hline IT_SRo & Italy & 1999-2004, 2006-2007, 2009, 2012 & 2.05 & 0.70 & ENF & doi:10.18140/FLX/1440176 \\
\hline IT_Tor & Italy & 2010-2014 & 0.98 & 2.54 & GRA & doi:10.18140/FLX/1440237 \\
\hline NL_Hor & Netherlands & 2004-2005, 2007-2008, 2010 & 1.81 & 2.01 & GRA & doi:10.18140/FLX/1440177 \\
\hline NL_Loo & Netherlands & 1996-1997, 2000-2013 & 2.09 & 1.20 & ENF & doi:10.18140/FLX/1440178 \\
\hline RU_Fyo & Russia & $1999-2014$ & 2.09 & 1.19 & ENF & doi:10.18140/FLX/1440183 \\
\hline SD_Dem & Sudan & 2008 & 0.34 & 0.12 & SAV & doi:10.18140/FLX/1440186 \\
\hline SN_Dhr & Senegal & 2012 & 0.61 & 0.27 & SAV & doi:10.18140/FLX/1440246 \\
\hline US_AR_AR & United States & 2010-2011 & 0.57 & 0.68 & GRA & doi:10.18140/FLX/1440103 \\
\hline US_AR2 & United States & 2010-2011 & 0.54 & 0.59 & GRA & doi:10.18140/FLX/1440104 \\
\hline US_Blo & United States & 2000-2006 & 1.94 & 1.26 & ENF & doi:10.18140/FLX/1440068 \\
\hline US_Hal & United States & 1992, 1994-2001, 2004, 2006, 2009, 2011 & 2.58 & 1.91 & DBF & doi:10.18140/FLX/1440071 \\
\hline US_Me2 & United States & $2002,2004-2005,2007,2009-2010,2012-2014$ & 1.97 & 0.65 & ENF & doi:10.18140/FLX/1440079 \\
\hline US_Me6 & United States & 2014 & 0.82 & - & ENF & doi:10.18140/FLX/1440099 \\
\hline US_MMS & United States & 1999-2014 & 2.71 & 1.28 & DBF & doi:10.18140/FLX/1440083 \\
\hline US_NR1 & United States & 1999-2014 & 1.32 & 1.02 & ENF & doi:10.18140/FLX/1440087 \\
\hline US_Prr & United States & 2011 & - & 0.92 & ENF & doi:10.18140/FLX/1440113 \\
\hline US_SRG & United States & 2009-2014 & 0.41 & 0.42 & GRA & doi:10.18140/FLX/1440114 \\
\hline US_SRM & United States & 2004-2014 & 0.35 & 0.31 & Woody SAV & doi:10.18140/FLX/1440090 \\
\hline US_Ton & United States & 2002-2006, 2008-2014 & 1.02 & 0.50 & Woody SAV & doi:10.18140/FLX/1440092 \\
\hline US_UMB & United States & $2000-2014$ & 2.14 & 0.95 & DBF & doi:10.18140/FLX/1440093 \\
\hline US_UMd & United States & 2008-2013 & 1.90 & 1.09 & DBF & doi:10.18140/FLX/1440101 \\
\hline US_Var & United States & 2001-2004, 2006-2014 & 1.07 & 0.70 & GRA & doi:10.18140/FLX/1440094 \\
\hline US_WCr & United States & 2000-2003, 2005, 2011, 2013-2014 & 2.00 & 1.40 & DBF & doi:10.18140/FLX/1440095 \\
\hline US_Wkg & United States & $2005-2014$ & 0.28 & 0.35 & GRA & doi:10.18140/FLX/1440096 \\
\hline ZA_Kru & South Africa & 2002,2010 & 1.08 & 0.38 & SAV & doi:10.18140/FLX/1440188 \\
\hline ZM_Mon & Zambia & 2008 & 1.62 & 0.49 & DBF & doi:10.18140/FLX/1440189 \\
\hline
\end{tabular}

Table 2. Strength and significance of the correlation between the LAI and surface fluxes for site-year and multi-year average data. The correlation coefficients are shown for significant correlations at * $p \leq 0.05$ or at ** $p \leq 0.1$. "-" indicates that the correlation was not significant.

\begin{tabular}{lrrrrr|rrrrrr}
\hline & \multicolumn{4}{c}{ Site-years } & & \multicolumn{4}{c}{ Multi-year average } \\
\cline { 2 - 11 } & LE & $H$ & EF & GPP & NEE & LE & H & EF & GPP & NEE \\
\hline Savanna & $0.88^{*}$ & $-0.72^{*}$ & $0.89^{*}$ & $0.97^{*}$ & $-0.89^{*}$ & $0.94^{*}$ & $-0.96^{*}$ & $0.95^{*}$ & $0.99^{*}$ & $-0.90^{*}$ \\
Grassland & $0.65^{*}$ & $-0.71^{*}$ & $0.74^{*}$ & $0.86^{*}$ & - & $0.68^{*}$ & $-0.80^{*}$ & $0.79^{*}$ & $0.84^{*}$ & - \\
Evergreen broadleaf forest & $0.84^{*}$ & $-0.69^{*}$ & $0.83^{*}$ & $0.88^{*}$ & $-0.51^{*}$ & $0.87^{* *}$ & & $-0.87^{* *}$ & $0.96^{*}$ & - \\
Evergreen needleleaf forest & - & - & - & $0.84^{*}$ & $-0.58^{*}$ & - & & - & - & $0.89^{*}$ & $-0.57^{*}$ \\
Deciduous broadleaf forest & - & - & - & $0.47^{*}$ & $-0.33^{*}$ & - & & - & - & $0.65^{* *}$ & - \\
\hline
\end{tabular}

by one site with an above average LAI for all site-years. For the LAI versus NEE, a steep slope with a negative correlation was found in arid SAV and humid ENF. In other humid regions, the correlation was less steep.
To study how the correlations varied with climatic drivers of surface fluxes, we calculated the correlation coefficient of the fluxes versus precipitation $(P)$ and incoming shortwave radiation ( $\mathrm{Rg}$ ) (Fig. 8). In SAV, GRA, and EBF, the water fluxes showed a strong correlation with $P$, indicating that 

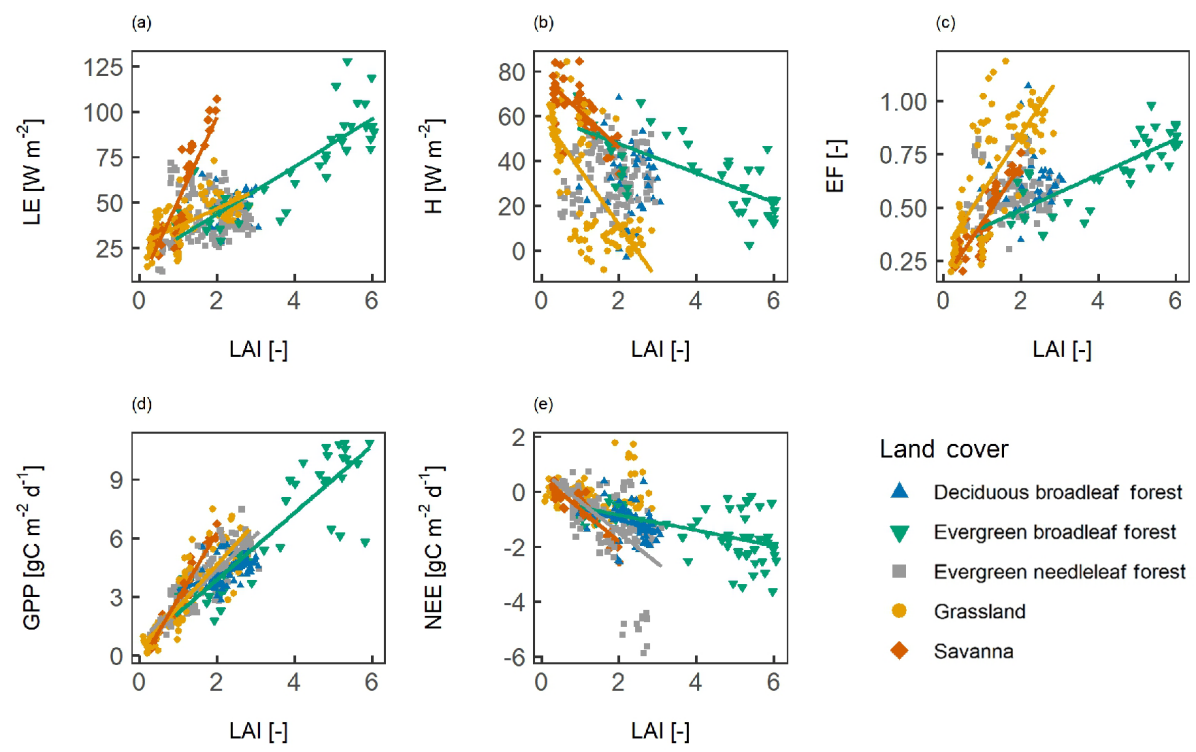

Figure 4. The spatio-temporal correlation between surface fluxes and leaf area index (LAI). Panels show (a) the latent heat flux ( $L E$ ), (b) the sensible heat flux $(H)$, (c) the evaporative fraction (EF), (d) gross primary productivity (GPP), and (e) net ecosystem exchange (NEE). A line indicates a significant correlation at $p<0.05$.
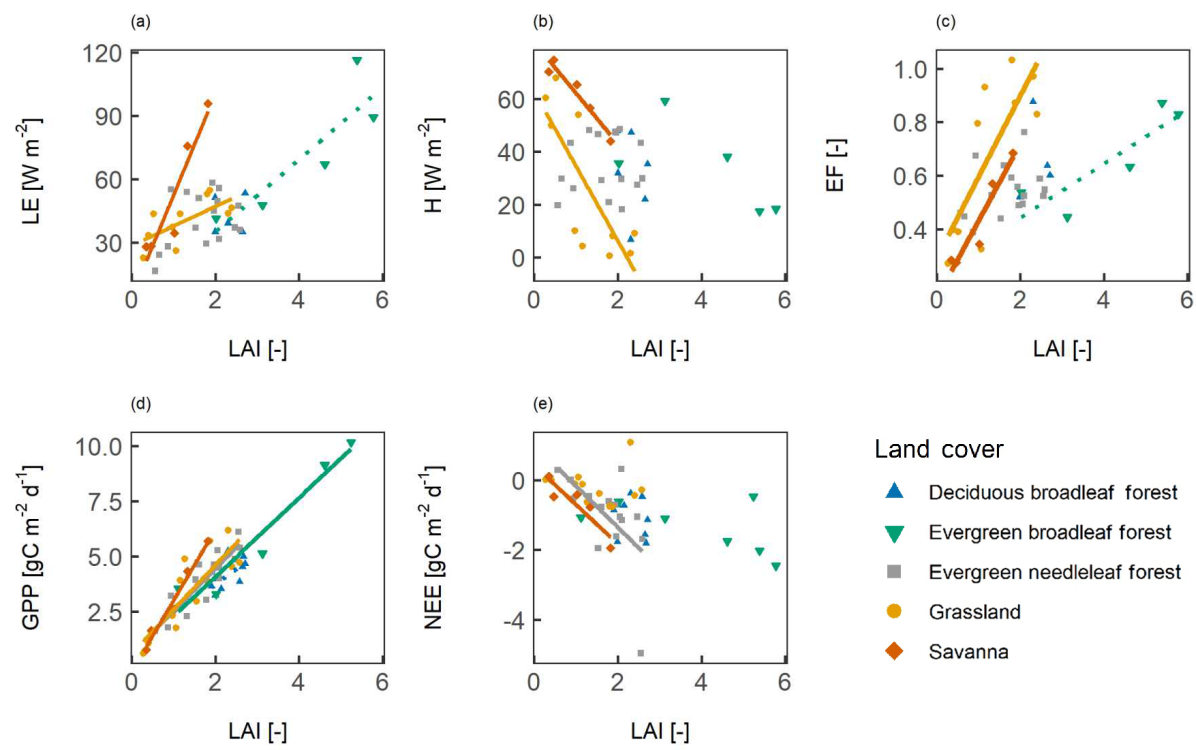

Land cover

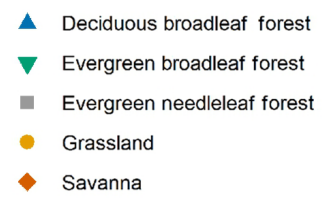

Figure 5. The spatial correlation between surface fluxes and the leaf area index (LAI). Panels show (a) the latent heat flux (LE), (b) the sensible heat flux $(H),(\mathbf{c})$ the evaporative fraction (EF), (d) gross primary productivity (GPP), and (e) net ecosystem exchange (NEE). All sites are included that have at least 3 years of LAI and flux data available. A line indicates a significant correlation at $p<0.05$, and a dashed line indicates a significant correlation at $p<0.1$.

water availability partly explained the spatio-temporal variability in surface fluxes. In ENF and DBF, there was a weak or non-existing correlation between $L E$ and $P$, but there was a strong correlation with $\mathrm{Rg}$. This indicates that available radiation was the primary driver of water and energy fluxes at these sites.

\section{Discussion}

The EBF site-years span a wide range of LAI values (LAI of $0.9-6.1$ ) and aridity conditions (AI of 0.3-9.3), and both are a potential limitation of our analysis for the EBF vegetation type. The uncertainty of the LAI retrieval in dense vegetation is higher than in other vegetation types due to saturation of the remotely sensed signal. The large range of climatic 

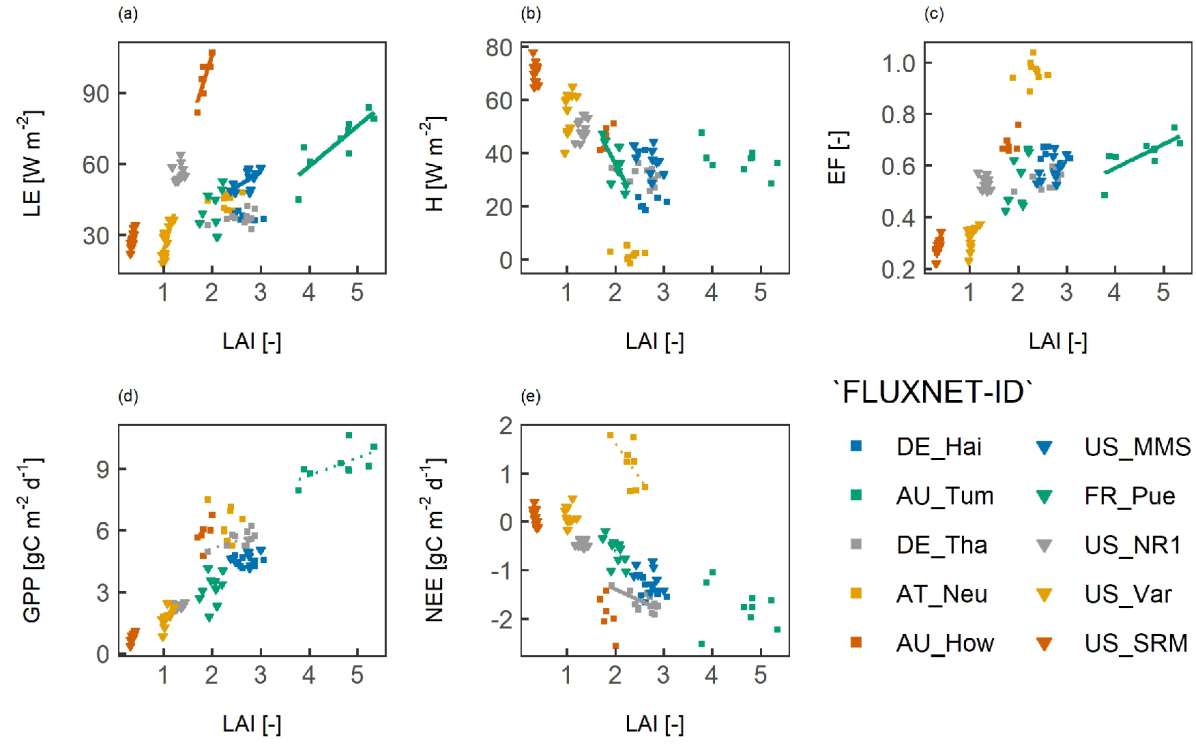

'FLUXNET-ID'

- DE_Hai $\nabla$ US_MMS

- AU_Tum $\nabla$ FR_Pue

- DE_Tha $\nabla$ US_NR1

- AT_Neu $\nabla$ US_Var

- AU_How $\nabla$ US_SRM

Figure 6. An illustration of the temporal correlation between the yearly average surface fluxes and the leaf area index (LAI). For each land cover type, two sites were selected that had the highest number of available data. The colours of the symbols indicate the land cover type as shown in Figs. 4 and 5. Panels show (a) the latent heat flux $(L E)$, (b) the sensible heat flux $(H)$, (c) the evaporative fraction (EF), (d) gross primary productivity (GPP), and (e) net ecosystem exchange (NEE). A line indicates a significant correlation at $p<0.05$, and a dashed line indicates a significant correlation at $p<0.1$.
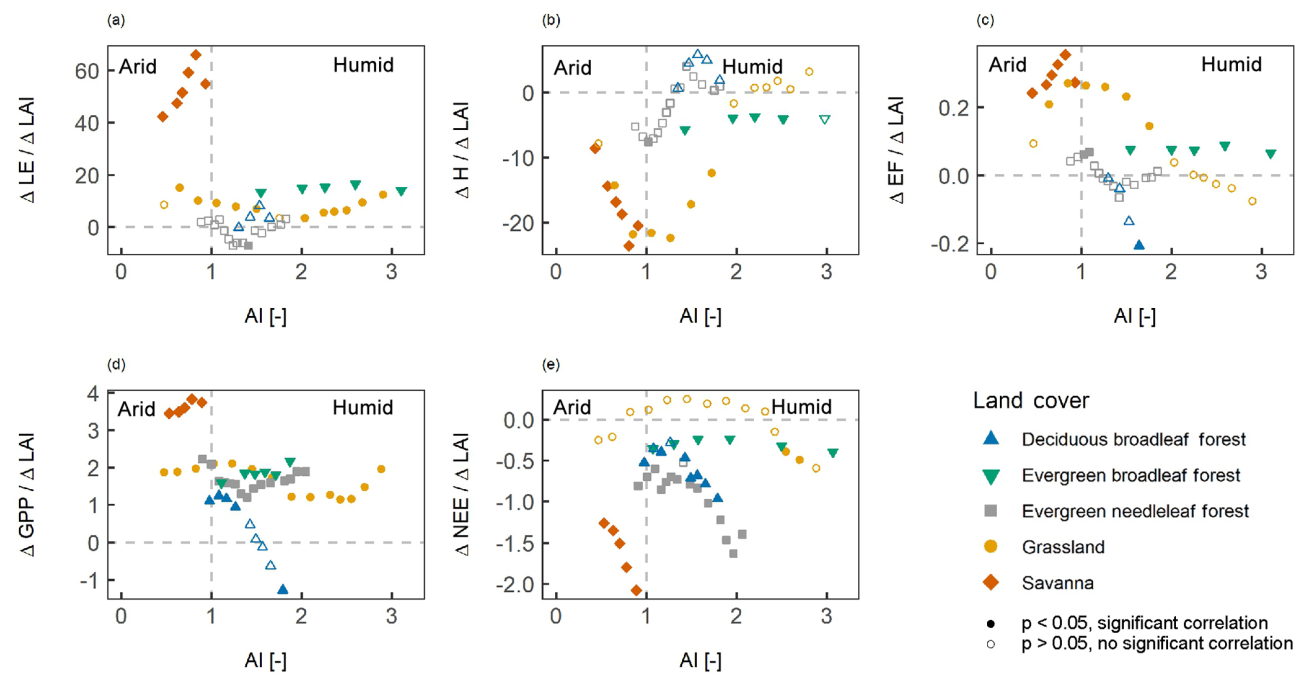

Figure 7. The effect of aridity on the relation between surface fluxes and the leaf area index (LAI). The slope of the correlation between the LAI and surface fluxes is shown for different aridity values for (a) the latent heat flux $(L E)$, (b) the sensible heat flux $(H)$, (c) the evaporative fraction (EF), (d) gross primary productivity (GPP), and (e) net ecosystem exchange (NEE). Each dot indicates the slope value for the 30 closest aridity values. The filled symbols indicate that the correlation was significant at $p<0.05$, whereas the hollow symbols indicate a non-significant correlation.

conditions indicates that our EBF site-years range from arid, water-limited conditions to humid conditions. Despite this high variability in site-years, the sites fell within one vegetation type.

The correlation between the LAI and respective water and energy fluxes ( $L E, H$, and $\mathrm{EF}$ ) varied with vegetation type and aridity. For the spatio-temporal and spatial variability, we found (1) strong (positive or negative) correlations and (partly) steep slopes for SAV and GRA, (2) a significant correlation but less steep slope for EBF, and (3) no significant correlations for ENF and DBF. With respect to the temporal variability, this pattern was similar for $L E$, but almost 


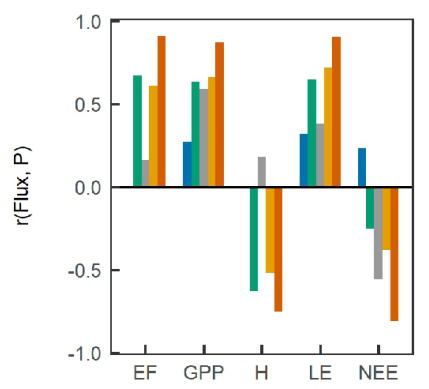

(b)

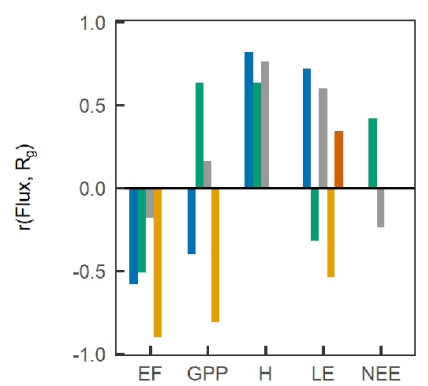

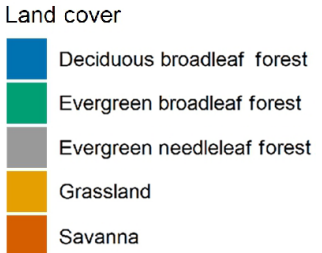

Figure 8. Water and energy control on surface fluxes. The correlation coefficient $(r)$ of site-year surface fluxes versus (a) the mean yearly precipitation $(P)$ and $(\mathbf{b})$ incoming shortwave radiation $(\mathrm{Rg})$. Each bar indicates a significant correlation at $p<0.05$.

no significant correlations were found between the LAI and the respective $H$ and EF for SAV and GRA. Evapotranspiration is the sum of transpiration, soil evaporation, and interception evaporation, and the magnitude of each component depends on the LAI. Transpiration increases with LAI at the cost of soil evaporation when there is sufficient moisture available (Gu et al., 2018; Wang et al., 2014). In arid climates, the transpiration component is higher than in wetter climates (Gu et al., 2018), and the link between transpiration and the LAI is particularly strong in these arid climates (Sun et al., 2019). When soil moisture is deficient and vegetation encounters a high evaporative demand, stomatal control is stronger (Mallick et al., 2016). This accelerates a strong stomatal coupling between the LAI and $L E$ and could explain the strong correlation between the LAI and the respective $L E, H$, and EF that was found in SAV and arid GRA. Soil water deficiency and high evaporative demand leads to a high increase in $L E$, for a small increase in LAI, which could explain the steep(er) slope in arid GRA and SAV vegetation.

In forests, soil evaporation is low, whereas interception evaporation is high. The elevated interception evaporation is due to the large leaf area (both green leaves included in the LAI and brown leaves after leaf senescence) with a high canopy water storage capacity and a high turbulence, enhancing fast evaporation (De Jong and Jetten, 2007). In EBF, interception evaporation contributes to up to $30 \%$ of the total evapotranspiration (Wei et al., 2017; Gu et al., 2018). This could explain the strong correlation between the LAI and the respective water and energy fluxes in EBF. A high interception evaporation was, however, also reported for temperate and boreal forest (Miralles et al., 2011); however, for the latter forest types, we found no correlation between the LAI and water and energy fluxes. The ENF and DBF sites were found in humid regions, and fluxes were primarily energy-limited. At these energy-limited sites, the LAI played a weak or nonexistent role in controlling surface fluxes. This indicates a weak or non-existent vegetation control on surface water and energy fluxes at energy-limited sites. This is in line with a low land-atmosphere coupling at energy-limited sites (Ferguson et al., 2012).
In contrast to the results for water and energy fluxes, the spatio-temporal and spatial correlation between GPP and LAI was strong across all vegetation types and (almost) all aridity gradients. A strong link between the LAI and carbon uptake on a yearly timescale over all vegetation types is expected, as plants try to optimize carbon gain and would generally not display leaves with a negative carbon balance. A strong link between the LAI and the mean yearly GPP was also shown by Hashimoto et al. (2012). However, other studies found a weak link between the LAI and GPP on annual timescales (Law et al., 2002). In contrast to the spatial variability, year-to-year variability in GPP was only correlated with LAI at some sites. Water availability is an important driver of temporal variability in GPP (Williams and Albertson, 2004; Kutsch et al., 2008), and GPP is strongly reduced under drought conditions (Vicca et al., 2016). The effect of drought is also visible in the reduced LAI, although on a longer timescale of 1 or 2 years in forests (Le Dantec et al., 2000; Kim et al., 2017). This different response time to water availability for forest LAI and GPP could partly explain the absence of a temporal correlation for some of the sites. The spatial correlation between the LAI and NEE was less strong compared with the GPP, which is in agreement with the results of Chen et al. (2019). The NEE is the sum of carbon uptake by the vegetation (GPP) and carbon loss by ecosystem respiration. Ecosystem respiration varies with climate and soil carbon storage, which are not directly related to the LAI. This could explain the absence of a correlation between the LAI and NEE.

These results partly confirmed our hypothesis. As hypothesized, the correlation between the LAI and surface fluxes was strong in arid regions for water and energy fluxes, and the correlation was absent in humid ENF and DBF. For humid EBF, however, we found a strong correlation between the LAI and water and energy fluxes, and the correlation with the LAI was strong across all aridity gradients for GPP. While carbon uptake is the primary goal of vegetation, independent of the aridity gradient, ecosystem water loss inevitably comes with carbon uptake but also depends on the 
vapour pressure deficit, available radiation, and soil moisture, which are not directly linked to the LAI.

Our statistical analysis cannot be used to study causality between the LAI and surface fluxes or to study vegetation control on the surface fluxes. The correlation between the LAI and water fluxes is confounded by the effect of soil moisture, especially in arid and semi-arid ecosystems, where both canopy development and $L E$ increase with water availability (Kergoat, 1998; Mallick et al., 2018). Similarly, precipitation is the main controller for spatial variability in both vegetation and GPP (Koster et al., 2014). Furthermore, the LAI is related to vegetation properties, but it is not a direct measure of canopy conductance; despite this, there are similarities, with previous studies showing the stomatal or vegetation control on surface fluxes. A strong vegetation control on water and energy fluxes in arid and semi-arid regions has been shown on timescales of days or shorter (e.g. Mallick et al., 2016, 2018); our study also shows that, on large spatiotemporal scale, the correlation between LAI and respective water and energy fluxes is strongest in arid regions. For EBF, however, we found a strong spatial correlation of vegetation versus the respective water and energy fluxes, whereas Padrón et al. (2017) showed that vegetation control in equatorial regions was absent. An interesting follow-up study would be to link stomatal control for different vegetation types (De Kauwe et al., 2017) to the canopy-scale pattern investigated in this study.

Our analyses provide insight into how and when the vegetation LAI is related to surface fluxes. The results show that the LAI is a good predictor of spatial variability in GPP across different vegetation types and aridity gradients. Furthermore, the analysis suggests that the LAI could be used to describe canopy-scale spatio-temporal variability in water and energy fluxes in SAV, GRA, and EBF. However, the LAI is not a good predictor for water and energy fluxes in ENF and DBF nor for NEE. It is important to be aware of these limitations when using the LAI to describe or estimate water, energy, and carbon fluxes in climate models or extrapolation methods. This study provides insight into the link between surface fluxes and the LAI and could be used to improve predictions of the effects of land cover change on surface fluxes.

\section{Conclusions}

The objective of this study was to gain insight into the link between the vegetation LAI and land-atmosphere fluxes for different vegetation types along an aridity gradient. We studied this link at a large spatio-temporal scale using flux tower measurements of water, energy, and carbon, combined with satellite-derived LAI data. The data analysis led to the following conclusions.

The link between the LAI and the respective water and energy fluxes depends on vegetation type and aridity. The correlation of the LAI with water and energy fluxes is strong in SAV, GRA, and EBF. In DBF and ENF, however, no significant correlation was found. Contrary to water and energy fluxes, the spatial correlation between the LAI and GPP was strong and independent of the vegetation type and aridity. This suggests that using the LAI to model or extrapolate surface fluxes of water and energy is very possible in SAV, GRA, and EBF, but it is limited in DBF and ENF.

As hypothesized, the link between the LAI and water and energy fluxes was strong in arid, water-limited conditions and was absent or weak for humid, radiation-limited conditions. EBF, which was found over a high range of aridity conditions, although mostly in humid environments, forms an exception: the spatial correlation between the LAI and the respective water and energy fluxes was strong, despite the overall humid conditions.

This research - facilitated by the recent availability of large global datasets of remotely sensed LAI, flux tower data, and cloud-computing platforms - has added to the understanding of the LAI interaction with surface fluxes and could help to improve modelling or extrapolating surface fluxes.

Data availability. The FLUXNET2015 dataset is available from https://fluxnet.org/data/fluxnet2015-dataset/ (Lawrence Berkeley National Laboratory, last access: January 2019). Flux measurements for the two OzFlux sites are available from http://data.ozflux.org.au/ portal/pub/listPubCollections.jspx (James Cook University, last access: February 2019). Leaf area index (LAI) data (the MCD15A3H data product, https://lpdaac.usgs.gov/products/mcd15a3hv006/, LP DAAC, last access: August 2019) were acquired from https://code. earthengine.google.com/ (last access: August 2019, Myneni et al., 2015).

Author contributions. The data analyses were carried out by AJHvD in close consultation with KM, MS, MM, MH, and AJT. AJHvD prepared the draft of the paper; all authors contributed to discussions and were involved in writing the final paper.

Competing interests. The authors declare that they have no conflict of interest.

Acknowledgements. We also acknowledge Michael Liddell for providing the data from two OzFlux research sites. We further acknowledge the FLUXNET community for acquiring and sharing the eddy covariance data including the following networks: AmeriFlux, AfriFlux, AsiaFlux, CARBOAFRICA, CarboEuropeIP, CARBOITALY, CARBOMONT, ChinaFlux, Fluxnet-Canada, GreenGrass, ICOS, KoFlux, LBA, NECC, OzFlux-TERN, TCOS-Siberia, and USCCC. The FLUXNET eddy covariance data processing and harmonization was carried out by the European Fluxes Database Cluster, the AmeriFlux Management Project, and the Fluxdata project of FLUXNET, with support from the CDIAC and the ICOS Ecosystem Thematic Centre, and the OzFlux, ChinaFlux, and AsiaFlux 
offices. The ERA-Interim reanalysis data are provided by ECMWF and processed by LSCE.

Financial support. This research has been supported by the Luxembourg National Research Fund (FNR; grant no. PRIDE15/10623093/HYDROCSI).

Review statement. This paper was edited by Eyal Rotenberg and reviewed by two anonymous referees.

\section{References}

Asner, G. P., Scurlock, J. M. O., and Hicke, J. A.: Global synthesis of leaf area index observations: implications for ecological and remote sensing studies, Global Ecol. Biogeogr., 12, 191-205, https://doi.org/10.1046/j.1466-822X.2003.00026.x, 2003.

Baldocchi, D., Falge, E., Gu, L., Olson, R., Hollinger, D., Running, S., Anthoni, P., Bernhofer, C., Davis, K., Evans, R., Fuentes, J., Goldstein, A., Katul, G., Law, B., Lee, X., Malhi, Y., Meyers, T., Munger, W., Oechel, W., Paw, U. K. T., Pilegaard, K., Schmid, H. P., Valentini, R., Verma, S., Vesala, T., Wilson, K., and Wofsy, S.: FLUXNET: A New Tool to Study the Temporal and Spatial Variability of Ecosystem-Scale Carbon Dioxide, Water Vapor, and Energy Flux Densities, B. Am. Meteorol. Soc., 82, 2415-2434, https://doi.org/10.1175/15200477(2001)082<2415:FANTTS>2.3.CO;2, 2001.

Barcza, Z., Kern, A., Haszpra, L., and Kljun, N.: Spatial representativeness of tall tower eddy covariance measurements using remote sensing and footprint analysis, Agr. Forest Meteorol., 149, 795-807, https://doi.org/10.1016/j.agrformet.2008.10.021, 2009.

Bates, C. G. and Henry, A. J.: Second phase of streamflow experiment at Wagon Wheel Gap, Colo, Mon. Weather Rev., 56, 79-80, https://doi.org/10.1175/15200493(1928)56<79:sposea>2.0.co;2, 1928.

Beer, C., Reichstein, M., Ciais, P., Farquhar, G. D., and Papale, D.: Mean annual GPP of Europe derived from its water balance, Geophys. Res. Lett., 34, L05401, https://doi.org/10.1029/2006g1029006, 2007.

Chen, S., Zou, J., Hu, Z., and Lu, Y.: Climate and Vegetation Drivers of Terrestrial Carbon Fluxes: A Global Data Synthesis, Adv. Atmos. Sci., 36, 679-696, https://doi.org/10.1007/s00376-0198194-y, 2019.

Costa, M. H., Biajoli, M. C., Sanches, L., Malhado, A. C. M., Hutyra, L. R., da Rocha, H. R., Aguiar, R. G., and de Araújo, A. C.: Atmospheric versus vegetation controls of Amazonian tropical rain forest evapotranspiration: Are the wet and seasonally dry rain forests any different?, J. Geophys. Res.-Biogeo., 115, G04021, https://doi.org/10.1029/2009jg001179, 2010.

Cramer, W., Bondeau, A., Woodward, F. I., Prentice, I. C., Betts, R. A., Brovkin, V., Cox, P. M., Fisher, V., Foley, J. A., Friend, A. D., Kucharik, C., Lomas, M. R., Ramankutty, N., Sitch, S., Smith, B., White, A., and Young-Molling, C.: Global response of terrestrial ecosystem structure and function to $\mathrm{CO}_{2}$ and climate change: Results from six dynamic global vegetation models,
Glob. Change Biol., 7, 357-373, https://doi.org/10.1046/j.13652486.2001.00383.x, 2001.

De Jong, S. M. and Jetten, V. G.: Estimating spatial patterns of rainfall interception from remotely sensed vegetation indices and spectral mixture analysis, Int. J. Geogr. Inf. Sci., 21, 529-545, https://doi.org/10.1080/13658810601064884, 2007.

De Kauwe, M. G., Medlyn, B. E., Knauer, J., and Williams, C. A.: Ideas and perspectives: how coupled is the vegetation to the boundary layer?, Biogeosciences, 14, 4435-4453, https://doi.org/10.5194/bg-14-4435-2017, 2017.

Duursma, R. A., Kolari, P., Perämmäki, M., Pulkkinen, M., Mäkelä, A., Nikinmaa, E., Hari, P., Aurela, M., Berbigier, P., Bernhofer, C., Grünwald, T., Loustau, D., Mölder, M., Verbeeck, H., and Vesala, T.: Contributions of climate, leaf area index and leaf physiology to variation in gross primary production of six coniferous forests across Europe: A model-based analysis, Tree Physiol., 29, 621-639, https://doi.org/10.1093/treephys/tpp010, 2009.

Esau, I. N. and Lyons, T. J.: Effect of sharp vegetation boundary on the convective atmospheric boundary layer, Agr. Forest Meteorol., 114, 3-13, https://doi.org/10.1016/S0168-1923(02)00154-5, 2002.

Evaristo, J. and McDonnell, J. J.: Global analysis of streamflow response to forest management, retracted article, Nature, 570, 455461, https://doi.org/10.1038/s41586-019-1306-0, 2019.

Fang, H., Baret, F., Plummer, S., and Schaepman-Strub, G.: An Overview of Global Leaf Area Index (LAI): Methods, Products, Validation, and Applications, Rev. Geophys., 57, 739-799, https://doi.org/10.1029/2018rg000608, 2019.

Fei, S., Desprez, J. M., Potter, K. M., Jo, I., Knott, J. A., and Oswalt, C. M.: Divergence of species responses to climate change, Sci. Adv., 3, e1603055, https://doi.org/10.1126/sciadv.1603055, 2017.

Ferguson, C. R., Wood, E. F., and Vinukollu, R. K.: A Global Intercomparison of Modeled and Observed LandAtmosphere Coupling, J. Hydrometeorol., 13, 749-784, https://doi.org/10.1175/jhm-d-11-0119.1, 2012.

Forkel, M., Drüke, M., Thurner, M., Dorigo, W., Schaphoff, S., Thonicke, K., Von Bloh, W., and Carvalhais, N.: Constraining modelled global vegetation dynamics and carbon turnover using multiple satellite observations, Sci. Rep., 9, 18757, https://doi.org/10.1038/s41598-019-55187-7, 2019.

Gómez, J. A., Giráldez, J. V., and Fereres, E.: Rainfall interception by olive trees in relation to leaf area, Agr. Water Manage., 49, 65-76, https://doi.org/10.1016/S0378-3774(00)00116-5, 2001.

Gu, C., Ma, J., Zhu, G., Yang, H., Zhang, K., Wang, Y., and Gu, C.: Partitioning evapotranspiration using an optimized satellitebased ET model across biomes, Agr. Forest Meteorol., 259, 355363, https://doi.org/10.1016/j.agrformet.2018.05.023, 2018.

Hashimoto, H., Wang, W., Milesi, C., White, M. A., Ganguly, S., Gamo, M., Hirata, R., Myneni, R. B., and Nemani, R. R.: Exploring Simple Algorithms for Estimating Gross Primary Production in Forested Areas from Satellite Data, Remote Sens., 4, 303-326, https://doi.org/10.3390/rs4010303, 2012.

Heinsch, F. A., Zhao, M., Running, S. W., Kimball, J. S., Nemani, R. R., Davis, K. J., Bolstad, P. V., Cook, B. D., Desai, A. R., Ricciuto, D. M., Law, B. E., Oechel, W. C., Kwon, H., Luo, H., Wofsy, S. C., Dunn, A. L., Munger, J. W., Baldocchi, D. D., Xu, L., Hollinger, D. Y., Richardson, A. D., Stoy, P. C., Siqueira, M. B. S., Monson, R. K., Burns, S. P., and Flanagan, 
L. B.: Evaluation of remote sensing based terrestrial productivity from MODIS using regional tower eddy flux network observations, IEEE Trans. Geosci. Remote Sens., 44, 1908-1923, https://doi.org/10.1109/TGRS.2005.853936, 2006.

Hoek van Dijke, A. J., Mallick, K., Teuling, A. J., Schlerf, M., Machwitz, M., Hassler, S. K., Blume, T., and Herold, M.: Does the Normalized Difference Vegetation Index explain spatial and temporal variability in sap velocity in temperate forest ecosystems?, Hydrol. Earth Syst. Sci., 23, 2077-2091, https://doi.org/10.5194/hess-23-2077-2019, 2019.

Iio, A., Hikosaka, K., Anten, N. P. R., Nakagawa, Y., and Ito, A.: Global dependence of field-observed leaf area index in woody species on climate: a systematic review, Global Ecol. Biogeogr., 23, 274-285, https://doi.org/10.1111/geb.12133, 2014.

James Cook University: OzFlux data, available at: http: //data.ozflux.org.au/portal/pub/listPubCollections.jspx, last access: February 2019.

Jeong, S. J., Ho, C. H., Gim, H. J., and Brown, M. E.: Phenology shifts at start vs. end of growing season in temperate vegetation over the Northern Hemisphere for the period 1982-2008, Glob. Change Biol., 17, 2385-2399, https://doi.org/10.1111/j.13652486.2011.02397.x, 2011.

Jia, X., Zha, T. S., Wu, B., Zhang, Y. Q., Gong, J. N., Qin, S. G., Chen, G. P., Qian, D., Kellomäki, S., and Peltola, H.: Biophysical controls on net ecosystem $\mathrm{CO}_{2}$ exchange over a semiarid shrubland in northwest China, Biogeosciences, 11, 4679-4693, https://doi.org/10.5194/bg-11-4679-2014, 2014.

Jung, M., Reichstein, M., Margolis, H. A., Cescatti, A., Richardson, A. D., Arain, M. A., Arneth, A., Bernhofer, C., Bonal, D., Chen, J., Gianelle, D., Gobron, N., Kiely, G., Kutsch, W., Lasslop, G., Law, B. E., Lindroth, A., Merbold, L., Montagnani, L., Moors, E. J., Papale, D., Sottocornola, M., Vaccari, F., and Williams, C.: Global patterns of land-atmosphere fluxes of carbon dioxide, latent heat, and sensible heat derived from eddy covariance, satellite, and meteorological observations, J. Geophys. Res.-Biogeo., 116, G00J07, https://doi.org/10.1029/2010JG001566, 2011.

Kergoat, L.: A model for hydrological equilibrium of leaf area index on a global scale, J. Hydrol., 212/213, 268-286, https://doi.org/10.1016/S0022-1694(98)00211-X, 1998.

Kim, J., Guo, Q., Baldocchi, D. D., Leclerc, M. Y., Xu, L., and Schmid, H. P.: Upscaling fluxes from tower to landscape: Overlaying flux footprints on high-resolution (IKONOS) images of vegetation cover, Agr. Forest Meteorol., 136, 132-146, https://doi.org/10.1016/j.agrformet.2004.11.015, 2006.

Kim, K., Wang, M.-c., Ranjitkar, S., Liu, S.-h., Xu, J.-c., and Zomer, R. J.: Using leaf area index (LAI) to assess vegetation response to drought in Yunnan province of China, J. Mt. Sci., 14, 1863-1872, https://doi.org/10.1007/s11629-016-3971-x, 2017.

Kirchner, J. W., Berghuijs, W. R., Allen, S. T., Hrachowitz, M., Hut, R., and Rizzo, D. M.: Streamflow response to forest management, Nature, 578, E12-E15, https://doi.org/10.1038/s41586020-1940-6, 2020.

Köppen, W.: Das geographische System der Klimate, in: Handbuch der Klimatologie, edited by: Köppen, W., and Geiger, G., Gebrüder Borntraeger, Berlin, 1936.

Koster, R. D., Walker, G. K., Collatz, G. J., and Thornton, P. E.: Hydroclimatic Controls on the Means and Variability of Vegetation Phenology and Carbon Uptake, J. Clim., 27, 5632-5652, https://doi.org/10.1175/jcli-d-13-00477.1, 2014.
Kutsch, W. L., Hanan, N., Scholes, B., McHugh, I., Kubheka, W., Eckhardt, H., and Williams, C.: Response of carbon fluxes to water relations in a savanna ecosystem in South Africa, Biogeosciences, 5, 1797-1808, https://doi.org/10.5194/bg-5-17972008, 2008.

Law, B. E., Falge, E., Gu, L., Baldocchi, D. D., Bakwin, P., Berbigier, P., Davis, K., Dolman, A. J., Falk, M., Fuentes, J. D., Goldstein, A., Granier, A., Grelle, A., Hollinger, D., Janssens, I. A., Jarvis, P., Jensen, N. O., Katul, G., Mahli, Y., Matteucci, G., Meyers, T., Monson, R., Munger, W., Oechel, W., Olson, R., Pilegaard, K., Paw U, K. T., Thorgeirsson, H., Valentini, R., Verma, S., Vesala, T., Wilson, K., and Wofsy, S.: Environmental controls over carbon dioxide and water vapor exchange of terrestrial vegetation, Agr. Forest Meteorol., 113, 97-120, https://doi.org/10.1016/S0168-1923(02)00104-1, 2002.

Lawrence Berkeley National Laboratory: FLUXNET2015 dataset, available at: https://fluxnet.fluxdata.org/data/ fluxnet2015-dataset/, last access: January 2019.

Lawrence, P. J. and Chase, T. N.: Investigating the climate impacts of global land cover change in the community climate system model, Int. J. Clim., 30, 2066-2087, https://doi.org/10.1002/joc.2061, 2010.

Le Dantec, V., Dufrêne, E., and Saugier, B.: Interannual and spatial variation in maximum leaf area index of temperate deciduous stands, Forest Ecol. Manag., 134, 71-81, https://doi.org/10.1016/S0378-1127(99)00246-7, 2000.

Liddell, M.: Cow Bay OzFlux tower site, OzFlux: Australian and New Zealand Flux Research and Monitoring, https://doi.org/102. 100.100/14244, 2013a.

Liddell, M.: Cape Tribulation Ozflux tower site, OzFlux: Australian and New Zealand Flux Research and Monitoring, https://doi.org/ 102.100.100/14242, 2013b.

Lindroth, A., Lagergren, F., Aurela, M., Bjarnadottir, B., Christensen, T., Dellwik, E., Grelle, A., Ibrom, A., Johansson, T., Lankreijer, H., Launiainen, S., Laurila, T., Mölder, M., Nikinmaa, E., Pilegaard, K., Sigurdsson, B. D., and Vesala, T.: Leaf area index is the principal scaling parameter for both gross photosynthesis and ecosystem respiration of Northern deciduous and coniferous forests, Tellus B, 60, 129-142, 2008.

Loveland, T. R., Reed, B. C., Brown, J. F., Ohlen, D. O., Zhu, Z., Yang, L., and Merchant, J. W.: Development of a global land cover characteristics database and IGBP DISCover from $1 \mathrm{~km}$ AVHRR data, Int. J. Remote Sens., 21, 1303-1330, https://doi.org/10.1080/014311600210191, 2000.

LP DAAC: MCD15A3H version 6 product, available at: https: //lpdaac.usgs.gov/products/mcd15a3hv006/, last access: August 2019.

Lu, Z., Miller, P. A., Zhang, Q., Wårlind, D., Nieradzik, L., Sjolte, J., Li, Q., and Smith, B.: Vegetation Pattern and Terrestrial Carbon Variation in Past Warm and Cold Climates, Geophys. Res. Lett., 46, 8133-8143, https://doi.org/10.1029/2019g1083729, 2019.

Mallick, K., Trebs, I., Boegh, E., Giustarini, L., Schlerf, M., Drewry, D. T., Hoffmann, L., Von Randow, C., Kruijt, B., Araùjo, A., Saleska, S., Ehleringer, J. R., Domingues, T. F., Ometto, J. P. H. B., Nobre, A. D., Luiz Leal De Moraes, O., Hayek, M., William Munger, J., and Wofsy, S. C.: Canopy-scale biophysical controls of transpiration and evaporation in the Amazon Basin, Hydrol. 
Earth Syst. Sci., 20, 4237-4264, https://doi.org/10.5194/hess-204237-2016, 2016.

Mallick, K., Toivonen, E., Trebs, I., Boegh, E., Cleverly, J., Eamus, D., Koivusalo, H., Drewry, D., Arndt, S. K., Griebel, A., Beringer, J., and Garcia, M.: Bridging Thermal Infrared Sensing and Physically-Based Evapotranspiration Modeling: From Theoretical Implementation to Validation Across an Aridity Gradient in Australian Ecosystems, Water Resour. Res., 54, 3409-3435, https://doi.org/10.1029/2017wr021357, 2018.

Miralles, D. G., De Jeu, R. A. M., Gash, J. H., Holmes, T. R. H., and Dolman, A. J.: Magnitude and variability of land evaporation and its components at the global scale, Hydrol. Earth Syst. Sci., 15, 967-981, https://doi.org/10.5194/hess-15-967-2011, 2011.

Mutanga, O. and Kumar, L.: Google earth engine applications, Remote Sens., 11, 591 pp., https://doi.org/10.3390/rs11050591, 2019.

Myneni, R., Knyazikhin, Y., and Park, T.: MCD15A2H MODIS/Terra+Aqua Leaf Area Index/FPAR 8-day L4 Global $500 \mathrm{~m}$ SIN Grid V006 [data set], NASA EOSDIS Land Processes DAAC, https://doi.org/10.5067/MODIS/MCD15A2H.006, 2015.

O'Toole, J. C. and Cruz, R. T.: Response of Leaf Water Potential, Stomatal Resistance, and Leaf Rolling to Water Stress, Plant Physiol., 65, 428-432, https://doi.org/10.1104/pp.65.3.428, 1980.

Pastorello, G., Trotta, C., Canfora, E., et al.: The FLUXNET2015 dataset and the ONEFlux processing pipeline for eddy covariance data, Scientific Data, 7, 225 pp., https://doi.org/10.1038/s41597020-0534-3, 2020

Padrón, R. S., Gudmundsson, L., Greve, P., and Seneviratne, S. I.: Large-Scale Controls of the Surface Water Balance Over Land: Insights From a Systematic Review and Meta-Analysis, Water Resour. Res., 53, 9659-9678, https://doi.org/10.1002/2017WR021215, 2017.

Perugini, L., Caporaso, L., Marconi, S., Cescatti, A., Quesada, B., De Noblet-Ducoudré, N., House, J. I., and Arneth, A.: Biophysical effects on temperature and precipitation due to land cover change, Environ. Res. Lett., 12, 053002, https://doi.org/10.1088/1748-9326/aa6b3f, 2017.

Prentice, I. C., Cramer, W., Harrison, S. P., Leemans, R., Monserud, R. A., and Solomon, A. M.: Special Paper: A Global Biome Model Based on Plant Physiology and Dominance, Soil Properties and Climate, J. Biogeogr., 19, 117-134, https://doi.org/10.2307/2845499, 1992.

Priestley, C. H. B. and Taylor, R. J.: On the Assessment of Surface Heat Flux and Evaporation Using Large-Scale Parameters, Mon. Weather Rev., 100, 81-92, 1972.

Reichstein, M., Falge, E., Baldocchi, D., Papale, D., Aubinet, M., Berbigier, P., Bernhofer, C., Buchmann, N., Gilmanov, T., Granier, A., Grünwald, T., Havránková, K., Ilvesniemi, H., Janous, D., Knohl, A., Laurila, T., Lohila, A., Loustau, D., Matteucci, G., Meyers, T., Miglietta, F., Ourcival, J.-M., Pumpanen, J., Rambal, S., Rotenberg, E., Sanz, M., Tenhunen, J., Seufert, G., Vaccari, F., Vesala, T., Yakir, D., and Valentini, R.: On the separation of net ecosystem exchange into assimilation and ecosystem respiration: review and improved algorithm, Glob. Change Biol., 11, 1424-1439, https://doi.org/10.1111/j.13652486.2005.001002.x, 2005.
Rosenzweig, C., Karoly, D., Vicarelli, M., Neofotis, P., Wu, Q., Casassa, G., Menzel, A., Root, T. L., Estrella, N., Seguin, B., Tryjanowski, P., Liu, C., Rawlins, S., and Imeson, A.: Attributing physical and biological impacts to anthropogenic climate change, Nature, 453, 353-357, https://doi.org/10.1038/nature06937, 2008.

Schmitt, M., Bahn, M., Wohlfahrt, G., Tappeiner, U., and Cernusca, A.: Land use affects the net ecosystem $\mathrm{CO}_{2}$ exchange and its components in mountain grasslands, Biogeosciences, 7, 2297 2309, https://doi.org/10.5194/bg-7-2297-2010, 2010.

Sellers, P. J., Dickinson, R. E., Randall, D. A., Betts, A. K., Hall, F. G., Berry, J. A., Collatz, G. J., Denning, A. S., Mooney, H. A., Nobre, C. A., Sato, N., Field, C. B., and Henderson-Sellers, A.: Modeling the Exchanges of energy, water and carbon between continents and the atmosphere, Science, 275, 502-509, https://doi.org/10.1126/science.275.5299.502 1997.

Shabanov, N. V., Dong, H., Wenze, Y., Tan, B., Knyazikhin, Y., Myneni, R. B., Ahl, D. E., Gower, S. T., Huete, A. R., Aragao, L. E. O. C., and Shimabukuro, Y. E.: Analysis and optimization of the MODIS leaf area index algorithm retrievals over broadleaf forests, IEEE Trans. Geosci. Remote Sens., 43, 18551865, https://doi.org/10.1109/TGRS.2005.852477, 2005.

Shao, J., Zhou, X., Luo, Y., Li, B., Aurela, M., Billesbach, D., Blanken, P. D., Bracho, R., Chen, J., Fischer, M., Fu, Y., Gu, L., Han, S., He, Y., Kolb, T., Li, Y., Nagy, Z., Niu, S., Oechel, W. C., Pinter, K., Shi, P., Suyker, A., Torn, M., Varlagin, A., Wang, H., Yan, J., Yu, G., and Zhang, J.: Biotic and climatic controls on interannual variability in carbon fluxes across terrestrial ecosystems, Agr. Forest Meteorol., 205, 11-22, https://doi.org/10.1016/j.agrformet.2015.02.007, 2015.

Si, Y., Schlerf, M., Zurita-Milla, R., Skidmore, A., and Wang, T.: Mapping spatio-temporal variation of grassland quantity and quality using MERIS data and the PROSAIL model, Remote Sens. Environ., 121, 415-425, https://doi.org/10.1016/j.rse.2012.02.011, 2012.

Sun, X., Wilcox, B. P., and Zou, C. B.: Evapotranspiration partitioning in dryland ecosystems: A global metaanalysis of in situ studies, J. Hydrol., 576, 123-136, https://doi.org/10.1016/j.jhydrol.2019.06.022, 2019.

Teuling, A. J., de Badts, E. A. G., Jansen, F. A., Fuchs, R., Buitink, J., Hoek van Dijke, A. J., and Sterling, S. M.: Climate change, reforestation/afforestation, and urbanization impacts on evapotranspiration and streamflow in Europe, Hydrol. Earth Syst. Sci., 23, 3631-3652, https://doi.org/10.5194/hess-23-3631-2019, 2019.

Teuling, A. J. and Hoek van Dijke, A. J.: Forest age and water yield, Nature, 578, E16-E18, https://doi.org/10.1038/s41586020-1941-5, 2020.

Turner, D. P., Ritts, W. D., Cohen, W. B., Gower, S. T., Zhao, M., Running, S. W., Wofsy, S. C., Urbanski, S., Dunn, A. L., and Munger, J. W.: Scaling Gross Primary Production (GPP) over boreal and deciduous forest landscapes in support of MODIS GPP product validation, Remote Sens. Environ., 88, 256-270, https://doi.org/10.1016/j.rse.2003.06.005, 2003.

Van Heerwaarden, C. C. and Teuling, A. J.: Disentangling the response of forest and grassland energy exchange to heatwaves under idealized land-atmosphere coupling, Biogeosciences, 11, 6159-6171, https://doi.org/10.5194/bg-11-6159-2014, 2014.

Vicca, S., Balzarolo, M., Filella, I., Granier, A., Herbst, M., Knohl, A., Longdoz, B., Mund, M., Nagy, Z., Pintér, K., Ram- 
bal, S., Verbesselt, J., Verger, A., Zeileis, A., Zhang, C., and Peñuelas, J.: Remotely-sensed detection of effects of extreme droughts on gross primary production, Sci. Rep., 6, 28269, https://doi.org/10.1038/srep28269, 2016.

Vuichard, N. and Papale, D.: Filling the gaps in meteorological continuous data measured at FLUXNET sites with ERA-Interim reanalysis, Earth Syst. Sci. Data, 7, 157-171, https://doi.org/10.5194/essd-7-157-2015, 2015.

Wagle, P., Xiao, X., Scott, R. L., Kolb, T. E., Cook, D. R., Brunsell, N., Baldocchi, D. D., Basara, J., Matamala, R., Zhou, Y., and Bajgain, R.: Biophysical controls on carbon and water vapor fluxes across a grassland climatic gradient in the United States, Agr. Forest Meteorol., 214/215, 293-305, https://doi.org/10.1016/j.agrformet.2015.08.265, 2015.

Wang, L., Good, S. P., and Caylor, K.: Global synthesis of vegetation control on evapotranspiration partitioning, Geophys. Res. Lett., 41, 6753-6757, https://doi.org/10.1002/2014GL061439, 2014.

Wei, Z., Yoshimura, K., Wang, L., Miralles, D. G., Jasechko, S., and Lee, X.: Revisiting the contribution of transpiration to global terrestrial evapotranspiration, Geophys. Res. Lett., 44, 2792-2801, https://doi.org/10.1002/2016gl072235, 2017.

Williams, C. A. and Albertson, J. D.: Soil moisture controls on canopy-scale water and carbon fluxes in an African savanna, Water Resour. Res., 40, W09302, https://doi.org/10.1029/2004wr003208, 2004.

Williams, C. A., Reichstein, M., Buchmann, N., Baldocchi, D., Beer, C., Schwalm, C., Wohlfahrt, G., Hasler, N., Bernhofer, C., Foken, T., Papale, D., Schymanski, S., and Schaefer, K.: Climate and vegetation controls on the surface water balance: Synthesis of evapotranspiration measured across a global network of flux towers, Water Resour. Res., 48, W06523, https://doi.org/10.1029/2011WR011586, 2012.

Williams, I. N. and Torn, M. S.: Vegetation controls on surface heat flux partitioning, and land-atmosphere coupling, Geophys. Res. Lett., 42, 9416-9424, https://doi.org/10.1002/2015gl066305, 2015.

Williams, I. N., Lu, Y., Kueppers, L. M., Riley, W. J., Biraud, S. C., Bagley, J. E., and Torn, M. S.: Land-atmosphere coupling and climate prediction over the U.S. Southern Great Plains, J. Geophys. Res.-Atmos., 121, 12125-112144, https://doi.org/10.1002/2016jd025223, 2016.
Woodwell, G. M., Whittaker, R. H., Reiners, W. A., Likens, G. E., Delwiche, C. C., and Botkin, D. B.: The Biota and the World Carbon Budget, Science, 199, 141-146, https://doi.org/10.1126/science.199.4325.141, 1978.

Xie, X., Li, A., Jin, H., Tan, J., Wang, C., Lei, G., Zhang, Z., Bian, J., and Nan, X.: Assessment of five satellite-derived LAI datasets for GPP estimations through ecosystem models, Sci. Total Environ., 690, 1120-1130, https://doi.org/10.1016/j.scitotenv.2019.06.516, 2019.

Xu, B., Park, T., Yan, K., Chen, C., Zeng, Y., Song, W., Yin, G., Li, J., Liu, Q., Knyazikhin, Y., and Myneni, R. B.: Analysis of global LAI/FPAR products from VIIRS and MODIS sensors for spatiotemporal consistency and uncertainty from 2012-2016, Forests, 9, 73-93, https://doi.org/10.3390/f9020073, 2018.

Xu, X., Liu, W., Scanlon, B. R., Zhang, L., and Pan, M.: Local and global factors controlling water-energy balances within the Budyko framework, Geophys. Res. Lett., 40, 6123-6129, https://doi.org/10.1002/2013gl058324, 2013.

Yan, H., Wang, S. Q., Billesbach, D., Oechel, W., Zhang, J. H., Meyers, T., Martin, T. A., Matamala, R., Baldocchi, D., Bohrer, G., Dragoni, D., and Scott, R.: Global estimation of evapotranspiration using a leaf area index-based surface energy and water balance model, Remote Sens. Environ., 124, 581-595, https://doi.org/10.1016/j.rse.2012.06.004, 2012.

Yan, K., Park, T., Yan, G., Liu, Z., Yang, B., Chen, C., Nemani, R. R., Knyazikhin, Y., and Myneni, R. B.: Evaluation of MODIS LAI/FPAR product collection 6, Part 2: Validation and intercomparison, Remote Sens., 8, 460-485, https://doi.org/10.3390/rs8060460, 2016.

Zheng, G. and Moskal, L. M.: Retrieving Leaf Area Index (LAI) Using Remote Sensing: Theories, Methods and Sensors, Sensors, 9, 2719-2745, https://doi.org/10.3390/s90402719, 2009. 